\title{
Estimation of selected biological parameters of the Purple Mangrove Crab Goniopsis pelii (Herklots 1851) from a tropical mangrove swamp in Nigeria
}

\author{
R.O. Moruf \\ Department of Fisheries and Aquaculture, Faculty of Agriculture, Bayero University, Kano, P.M.B. \\ 53011, Gwarzo Road, Kano, Kano State, Nigeria \\ Correspondence: tunjimoruf@gmail.com; (D) https://orcid.org/0000-0002-0459-0621 \\ Received: $7^{\text {th }}$ August 2019, Revised: $24^{\text {th }}$ May 2020, Accepted: $8^{\text {th }}$ June 2020
}

\begin{abstract}
The Purple Mangrove Crab, Goniopsis pelii is one of the more elusive crab species inhabiting most of the microhabitats in the mangrove ecosystem of Southern Nigeria. This study was carried out to investigate the size composition, growth pattern, diets, and reproductive biology of $G$. pelii from Abule-Eledu mangrove swamp in Lagos Lagoon, Nigeria. A total of 116 specimens were studied. Data revealed that the carapace length and total weight ranged from 2.5 to $4.9 \mathrm{~cm}(3.72 \pm 0.39)$ and from 11 to $37 \mathrm{~g}(23.90 \pm 4.21)$ respectively. The crab exhibited negative allometric growth pattern $(b<3)$, and the carapace lengthweight relationship was positively correlated $(r=0.577-0.900)$. The condition factor (K) ranged from 3.5-8.0 (male), 3.2-7.5 (female) and 3.4-8.0 (sexes combined). The highest K-values were recorded for the smaller size group (2.5 $2.9 \mathrm{~cm}$ ). In terms of sex, the male has the higher K-value (8.0). Identified food particles included plant materials, algae, detritus, diatoms, and protozoa. The sex ratio was 1:0.57 (male: female), and was significantly different from the theoretical ratio of $1: 1$. Fecundity ranged between 1.9 and 2.8 million eggs with egg diameter ranging from 0.26 to $0.38 \mathrm{~mm}$. Crabs with partial gonad development were predominant in the mangrove, while adults with fully ripe gonads were encountered occasionally throughout the study period. In this study, the reproductive indices and body conditions are indicators of a viable population.
\end{abstract}

Keywords: allometric growth, crab feeding, reproductive biology, Lagos Lagoon.

\section{Introduction}

Mangroves are salt-tolerant, characteristically complex plant communities occurring in sheltered coastline areas in the tropical and subtropical intertidal regions such as bays, estuaries, lagoons, and creeks (Venkataraman 2007). One of the more elusive crab species occurring in brackish water environments in Nigeria is the Purple Mangrove Crab (Goniopsis pelii Herklots, 1851), inhabiting almost every microhabitat in the mangrove ecosystems. The Purple Mangrove Crab populations are dependent on mangroves for shelter and food, hence any impact that significantly alters the 
mangrove ecosystem may affect them. Although the mangrove crab does not really constitute a food item for the coastal communities, they play a major ecological role in the mangrove ecosystem through processing fallen leaves for feeding (Usese et al. 2018). In Nigeria, mangroves are threatened by anthropogenic activities such as pollution and dredging as well as natural phenomenon like sea level rise (Lawal-Are et al. 2019)

The Purple Mangrove Crab is a brightly colored crab, having a dark carapace with white spots, and hairy red legs with white or yellow spots. Female crab has a wide abdomen for egg storage, while males have thin abdomen covering the gonopods. Most mangrove crabs are amphibious in habit and can be found around the intertidal areas with moist/ wet muddier regions of the mangrove (Moruf and Lawal-Are 2018). Crabs are mainly opportunistic feeders, while some are scavengers with plant-derived detritus comprising the main food consumed. In common with other benthic detritus feeding invertebrates, crabs are not indifferent to cannibalism when kept in captivity and even in the wild (Hill and O'Keefe 1992). Generally, crabs retain the ability to eat different things but tend to be best adapted for particular diets. According to Feller and Sitnik (1996), mangrove crabs have been observed feeding on mangrove propagules, insects, and organic material with special affinity for a foraging existence. They will eat anything that gets washed upon shores or in mangrove such as algae, carrion, seaweeds, debris and anything small enough to be grasped with the chelae, because their chelae and gastric mill are non-specialized (Moruf and Ojetayo 2017). However, mangrove crabs might have been overlooked as they are certainly able to shred leaf litter very effectively (Dobson et al. 2002). This combined with the general abundance and high biomass makes them potentially important in the dynamics of energy resources in mangrove ecosystems (Hill and O'Keeefe 1992).

Purple Mangrove Crab provides food for other species and reduces the insect population within the mangrove ecosystem. By eating the leaf litter and organic material around the mangrove roots, mangrove crabs contribute to nutrient cycling (Moruf and Ojetayo 2017). As little is known about the mangrove crabs of lagoon creeks in Lagos, this paper bears significance to provide baseline data on the biology of the Purple Mangrove Crab in the Abule-Eledu mangrove swamp of Lagos Lagoon, with particular emphasis on size composition, growth pattern, condition factor, feeding habits and reproductive biology.

\section{Materials and Methods}

\subsection{Study site}

The study was carried out in the mangrove swamp bordering the Abule-Eledu Creek (Figure 1), which forms part of the many sluggish tidal creeks that drain into the Lagos Lagoon, Nigeria (GPS coordinates: $6031.015^{\prime} \mathrm{N}, 3023.948$ 'E, elevation: $14 \mathrm{ft}(4.27 \mathrm{~m})$ above sea level. 


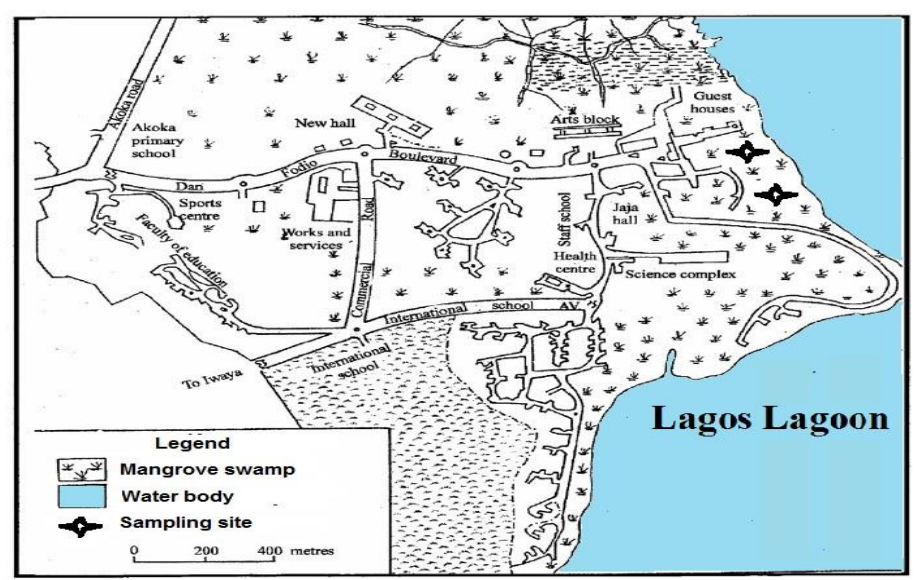

Fig. 1. Map of study location in mangrove swamps of Abule-Eledu Creek, Nigeria

\subsection{Sample collection}

Random sampling was carried out between 17.00 and 19.00 hours on monthly bases from March to July 2017. A total of 116 specimens of G. pelii (Figire 2) were caught from the mangrove swamps of Abule-Agege Creek using baited traps (Emmanuel 2009) and hand-picked using protective rubber gloves. Specimens were identified using published taxonomic keys (Schneider 1990) and immediately transported to the laboratory for further analysis.

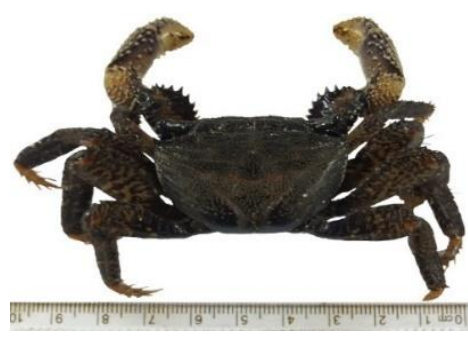

Fig. 2. Purple Mangrove Crab (Goniopsis pelii) (collected from mangrove swamps of Abule-Eledu Creek, Nigeria)

\subsection{Morphometric measurements}

The length of the crab was measured to the nearest $0.1 \mathrm{~cm}$ using a Vernier caliper and plotted against their respective frequencies. The total weight was measured in grams using Sartorius top loading balance (Model: DT1001A). The length-weight relationship of the crabs is represented using the equation (Pauly 1983) as follows:

$$
W=a L^{b}
$$


where, $\mathrm{W}=$ body weight $(\mathrm{g}), \mathrm{L}=$ carapace length $(\mathrm{cm}), \mathrm{a}=$ regression constant (intercept), and $\mathrm{b}=$ regression coefficient (slope).

The relationship was logarithm transformed into a straight-line (Parsons 1988) by

$$
\log W=\log a+b \log L
$$

Condition factor (K) of each crab was determined using the formula (Bannister 1976)

$$
\text { by, } \quad K=100 \times\left(\frac{W}{L^{b}}\right)
$$

\subsection{Stomach content analysis}

The cardiac stomach of each specimen was dissected, and the contents were extracted into a petri dish. The extracted contents were mixed with a little water and examined under a binocular microscope for the food types using the numerical and occurrence methods (Cortés 1998).

\subsection{Reproductive biology}

The sex was distinguished using the species conspicuous external morphological features, i.e. T-shaped abdomen of the male and the triangular or rounded aprons of the female (Schneider 1990). Sex ratio was tested for any deviation from the expected 1:1 ratio using Chi-square analysis. In fecund females, egg mass attached to the underside of the abdomen was removed for fecundity estimation. Fecundity was calculated as the number of eggs carried externally by the female. It was estimated by the gravimetric method (Kumar et al. 2000) from the ovaries at Stage III. The diameters of eggs per berried females (sub sample) were measured using an ocular micrometer. Gonadal development was determined using the criteria of Lawal-Are (2010) given below:

$$
\begin{array}{ll}
\text { Stage I: } & \text { No gonad development } \\
\text { Stage II: } & \text { Partial gonad development } \\
\text { Stage III: } & \text { Gonads extending in carapace, which are orange in colour } \\
\text { Stage IV: } & \text { Ripe running bright red gonads }
\end{array}
$$

\subsection{Data analysis}

Data were analyzed using Microsoft Excel 2010 and SPSS software. Test for goodness of fit was determined statistically using chi-square $\left(\chi^{2}\right)$ test on sex ratios of the species.

\section{Results and Discussion}

\subsection{Size composition}

Amongst mangrove macrobenthos, crabs are one of the most significant groups in terms of species, numbers and total biomass. Monthly abundance of G. pelii revealed 
that the highest occurrence was at the onset of wet season with $23.3 \%$ in May, while the lowest number was recorded in July 2017 (Figure 3).

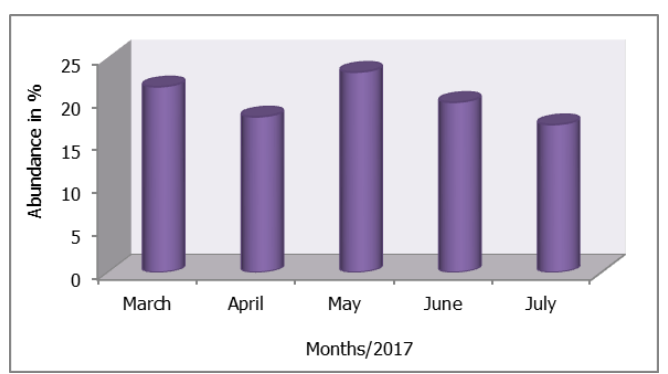

Fig. 3. Monthly collection of G. pelii $(\mathrm{N}=116)$ from the mangrove swamp of Abule-Eledu Creek, Lagos Lagoon

The crabs with carapace length between $3.50 \mathrm{~cm}$ and $3.90 \mathrm{~cm}$ was the most frequently occurring size group, with the length frequency polygon showing a unimodal size distribution during the sampling period (Figure 4). This report conformed to the work of Onadeko et al. (2015) on brachyuran crabs of the same study area, which showed the highest abundance in May of the year.

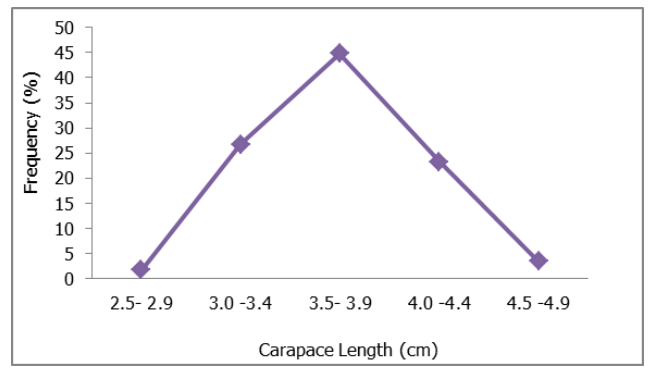

Fig. 4. Carapace length frequency distribution of $G$. pelii $(\mathrm{N}=116)$ from the mangrove swamp of Abule-Eledu Creek (March- July 2017)

\subsection{Growth pattern}

The growth pattern of the crabs was based on the length/weight relationship. The carapace length was between 2.5 and $4.9 \mathrm{~cm}$ and total weight between 11 and $37 \mathrm{~g}$. The carapace length-total weight of the crabs was transformed into a logarithm form as shown below:

Male G. pelii:

Female G. pelii:

$\log \mathrm{TW}=0.5299+1.4271 \log \mathrm{CL}$

Combined sexes:

$\log \mathrm{TW}=0.649+1.1988 \log \mathrm{CL}$

$\log \mathrm{TW}=0.148+2.1217 \log \mathrm{CL}$ 


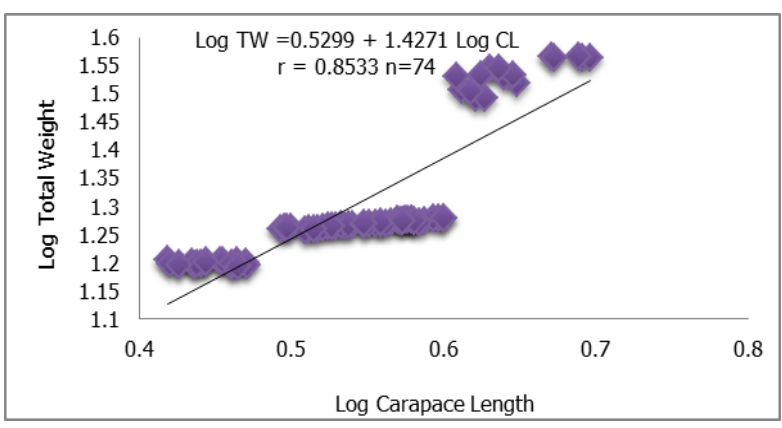

Fig. 5. Relationship of Log carapace length/Log Total Weight of male G. pelii from mangrove swamp of Abule-Eledu Creek (March - July 2017)

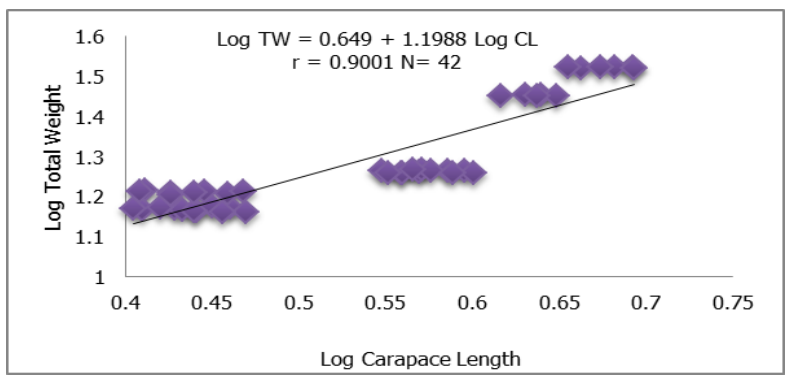

Fig. 6. Relationship of Log carapace length/Log Total Weight of female G. pelii from mangrove swamp of Abule-Eledu Creek (March - July 2017)

According to Figures 5, 6, and 7, the values of ' $b$ ' were 1.4271, 1.1988 and 2.1217 for the males, females and combined sexes respectively. These values showed that $G$. pelii exhibited a negative allometric growth pattern $(\mathrm{b}<3)$. The correlation coefficient $(\mathrm{r})$ was 0.8533 for the males, while 0.9001 for females and 0.5773 for combined sexes of G. pelii, showing correlation between the carapace length and weight.

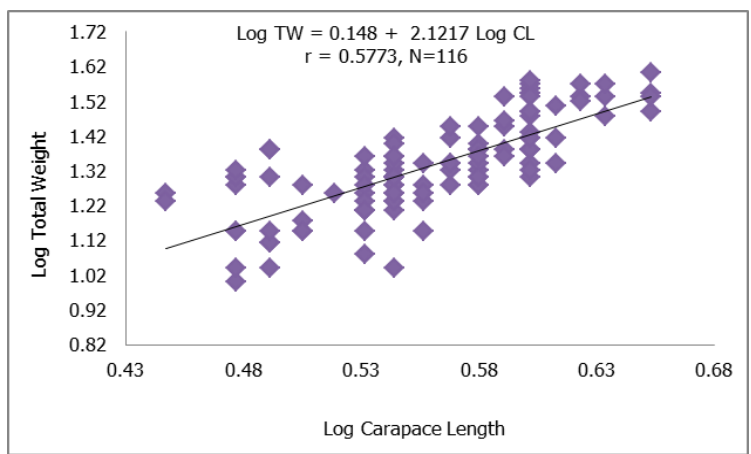

Fig. 7. Relationship of $\log$ carapace length/Log Total Weight of G. pelii from the mangrove swamp of Abule-Eledu Creek (March - July 2017) 
The relationships between the length and weight suggest that the crab weight could be estimated from its length regardless of the developmental stages. Another co-occurring mangrove crab, the Hairy Mangrove Crab, Sersema huzardii shows positive relationships between length and weight (Lawal-Are and Nwankwo 2011). Similarly, Moruf and Lawal-Are (2017a) reported a positive correlation for portunid crabs of Lagos Coast, suggesting that the higher the carapace length the more weight an individual possesses.

\subsection{Condition factor}

The variations in condition factor $(\mathrm{K})$ by size and sex of $G$. pelii from the Abule-Agege Mangrove Swamp are presented in Table 1. The K-values ranged from 3.5- 8.0 (male), 3.2 -7.5 (female) and 3.4 - 8.0 (combined sexes). The highest K-values were recorded for the small size $(2.5-2.9 \mathrm{~cm})$ group, while in terms of sex; the male had the higher Kvalue (8.0).

Table 1: Condition factor by sex and size of Goniopsis pelii.

\begin{tabular}{|c|c|c|c|c|c|c|c|c|c|c|c|c|}
\hline \multirow{2}{*}{$\begin{array}{l}\text { Carapace } \\
\text { length } \\
(\mathrm{cm})\end{array}$} & \multicolumn{4}{|c|}{ Male } & \multicolumn{4}{|c|}{ Female } & \multicolumn{4}{|c|}{ Combined Sex } \\
\hline & $\mathrm{N}$ & $\begin{array}{c}\mathrm{CL} \\
(\mathrm{cm})\end{array}$ & $\begin{array}{c}\mathrm{W} \\
(\mathrm{g})\end{array}$ & $\mathrm{K}$ & $\mathrm{N}$ & $\begin{array}{c}\mathrm{CL} \\
(\mathrm{cm})\end{array}$ & $\begin{array}{l}\mathrm{W} \\
(\mathrm{g})\end{array}$ & K & $\mathrm{N}$ & $\begin{array}{c}\mathrm{CL} \\
(\mathrm{cm})\end{array}$ & $\begin{array}{l}\mathrm{W} \\
(\mathrm{g})\end{array}$ & K \\
\hline $2.5-2.9$ & 18 & 2.7 & 15.7 & 8 & 11 & 2.7 & 14.8 & 7.5 & 2 & 2.7 & 15.7 & 8 \\
\hline $3.0-3.4$ & 16 & 3.1 & 18.2 & 6.1 & 8 & 2.9 & 16.2 & 6.6 & 31 & 3.1 & 17.5 & 5.9 \\
\hline $3.5-3.9$ & 24 & 3.7 & 18.8 & 3.7 & 12 & 3.5 & 18.2 & 4.3 & 52 & 3.7 & 18.6 & 3.7 \\
\hline $4.0-4.4$ & 11 & 4.2 & 33 & 4.5 & 5 & 4.2 & 28.2 & 3.8 & 27 & 4.2 & 30.7 & 4.1 \\
\hline $4.5-4.9$ & 5 & 4.7 & 36.6 & 3.5 & 6 & 4.7 & 33.4 & 3.2 & 4 & 4.7 & 35 & 3.4 \\
\hline & 74 & & & & 42 & & & & 116 & & & \\
\hline
\end{tabular}

$\mathrm{N}=$ Number of crabs, $\mathrm{CL}=$ Carapace length, $\mathrm{W}=$ Total weight, $\mathrm{K}=$ condition factor

In studies of population dynamics, high ' $\mathrm{k}$ ' values of a crab show favorable environmental conditions such as habitat and prey availability. It was observed from this study that the small - sized group had the highest condition factors, indicating successive growth as a result of molting activity. The older the crab, the more difficult it is for the crab to molt. On the average, the condition factors of the male G. pelii were higher than that of its female.

\subsection{Stomach contents}

Of the 116 examined specimens of G. pelii, $14(12 \%)$ of these had empty stomachs. The stomach contents consisted mainly of plant materials, filamentous algae, detritus, diatoms and protozoa. Plant materials showed the highest numerical count $(50.1 \%)$ and formed the most important food item, occurring in $97.1 \%$ of the crabs examined. Diatoms and detritus occurred in $92.2 \%$ and $85.3 \%$ of the stomachs respectively (Figure 8). G. pelii can be considered as herbivore-scavenger species as its diet contained a wide range of plant materials, filamentous algae, detritus, diatoms and protozoa. Except for protozoa, the broad spectrum of the food items ingested by $G$. 
pelii is of plant-origin while detritus is regarded as debris of any kind. This report is similar to what was recorded by Eteobong et al. (2016) on diet composition of G. pelii from South West Nigeria. The feeding habits of mangrove crabs play a vital role in the preservation of wetland environments by sifting through the sands, and they aerate the substrate and prevent anaerobic conditions.

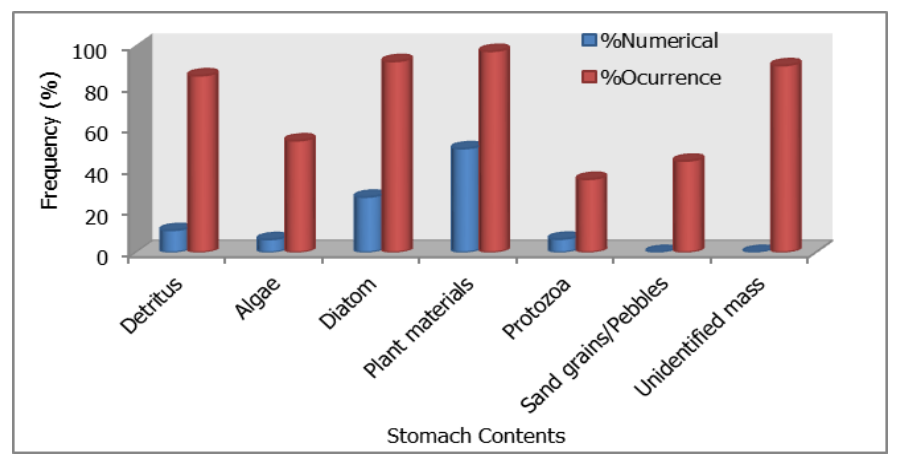

Fig. 8. Stomach content of $G$. pelii from the mangrove swamp of Abule-Eledu Creek

\subsection{Reproductive biology}

A total of 74 males and 42 females of $G$. pelii were examined giving a sex ratio of 1: 0.57 (male: female) which was significantly different $(\mathrm{P}<0.05)$ from the expected and theoretical ratio of 1:1. This is in contrary to the report of Eteobong et al. (2017) who reported more female than male G. pelii in Lagos Lagoon. Environment factors can influence the sex ratio of aquatic organism either directly or indirectly (Moruf et al. 2018)

Fecundity was determined using 18 mature females $(3.6-4.9 \mathrm{~cm}$ carapace length and 18.6-35.0 g weight) obtained only during the months of March and April. The fecundity ranged from 1.9 to 2.8 million eggs with egg diameter ranging between 0.26 and $0.38 \mathrm{~mm}$. Crablets with partial gonad development (Stage II) were predominant in the mangrove while ripe males and females (Stage IV) occurred occasionally throughout the study period (Table 2).

Table 2: Percentage occurrence of different maturity stages of gonads of $G$. pelii from the mangrove swamp of Abule-Eledu Creek (March - July 2017).

\begin{tabular}{crrrr}
\hline & \multicolumn{2}{c}{ Male } & \multicolumn{2}{c}{ Female } \\
\cline { 2 - 5 } Gonad Stages & Number & $\begin{array}{c}\% \\
\text { occurrence }\end{array}$ & Number & $\begin{array}{c}\% \\
\text { occurrence }\end{array}$ \\
\hline Stage I & 6 & 8.1 & 4 & 9.5 \\
Stage II & 41 & 55.4 & 20 & 47.6 \\
Stage III & 25 & 33.8 & 16 & 38.1 \\
Stage IV & 2 & 2.7 & 2 & 4.8 \\
Total & 74 & & 42 & \\
\hline
\end{tabular}


Fecundity in G. pelii was low when compared with what was reported in brachyuran species like Callinectes sapidus (mean of 3.2 million eggs) (Guillory et al. 1996) and Portunus validus (mean of 3 million eggs) (Moruf and Lawal-Are 2017b). According to Shields et al. (1990), variations in fecundity in crab might be caused by several ecological factors including habitat and biological constraints. The egg diameter of $G$. pelii ranged from 0.26 to $0.38 \mathrm{~mm}$ with a mean of $0.30 \mathrm{~mm}$. This result compared well with a study on a different species of estuarine crab, by Lawal-Are (2010) who reported an egg diameter range of 0.25 to $0.35 \mathrm{~mm}$ with a mean of $0.25 \mathrm{~mm}$ for Callinectes amnicola in the Lagos Lagoon.

\section{Conclusions}

Goniopsis pelii exhibits sexual dimorphism with males attaining larger sizes than females. As revealed by allometric growth, the crab weight can be estimated from its length. Reproductive biology and conditions of the species are indicators of viable population. The present study has provided baseline data which will serve as a useful source of information in the management and conservation of mangrove ecosystem resources. Further studies could assess reproductive activity using macroscopic and microscopic observations of gonad characteristics, trends of gonad indices, size at first sexual maturity, differences in the monthly sex ratio, estimation of Gonado-somatic Index etc.

\section{Acknowledgments}

Two anonymous reviewers are acknowledged for valuable comments on the initial draft of the manuscript.

\section{References}

Bannister JV. 1976. The length-weight relationship, condition factor, gut contents in the dolphin fish, Coryphaena hippurus L. in the Mediterranean. Journal of Fish Biology 9: 335-338.

Cortés E. 1998. Methods of studying fish feeding: reply. Canadian Journal of Fisheries and Aquatic Sciences 55(12): 27-38.

Dobson M, Magana A, Mathooko JM., Ndegwa FK. 2002. Detritivores in Kenyan highland streams: more evidence for the paucity of shredders in the tropics? Freshwater Biology 47: 909-919.

Emmanuel BE. 2009. Assessment of crab traps selectivity and efficiency in a tropical riparian swamp. African Journal of Biotechnology 8 (18): 4680-4684

Eteobong N, Fola-Mathews OO, Aghogho KD. 2017. Sex Ratio of Purple Lagoon Crabs Goniopsis Pelii (Herklots, 1851) From the Lagos Lagoon - Nigeria. Journal of Biology, Agriculture and Healthcare 7(9): 6-11.

Eteobong N, Lawal-Are AO, Bernard E. 2016. Diet composition of Purple Lagoon Crab Goniopsis pelii (Herklots, 1851) from South West Nigeria. Journal of Biology, Agriculture and Healthcare 6(21): 104112.

Feller IC, Sitnik M. 1996. Mangrove Ecology. Workshop Manual.565pp 
Guillory V, Prejean E, Bourgeois M, Burdon J, Merrell J. 1996. A biological and fisheries profile of the blue crab, Callinectes sapidus. L.A. Department of Wildlife and Fisheries Management Plan Series, 8(1): $210 \mathrm{pp}$.

Hill MP, O'Keefe JH. 1992. Some aspects of the ecology of the freshwater crab (Potamonautes perlatus Milne Edwards) in the upper reaches of the Buffalo River, eastern Cape Province, South Africa. South African Journal of Aquatic Sciences 18: 42-50.

Kumar MS, Ferguson G, Xiao Y, Hooper G., Venema S. 2000. Studies on reproductive biology and distribution of the blue swimmer crab (Portunus pelagicus) in South Australia waters. SARDI Research Report Series No. 47.

Lawal-Are AO, Nwankwo H. 2011. Biology of the Hairy Mangrove Crab, Sersema Huzardii (Decapoda: Grapsidae) from a Tropical Estuarine Lagoon. Journal of American Science 7 (7): 402-408.

Lawal-Are AO, Moruf RO, Oluseye-Are SO, Isola TO. 2019. Antioxidant defense system alternations in four crab species as a bio-indicator of environmental contamination. Bulletin UASVM Veterinary Medicine 76(1): 73-80.

Lawal-Are AO. 2010. Reproductive Biology of the Blue Crab, Callinectes amnicola in the Lagos Lagoon, Nigeria. Turkish Journal of Fish and Aquatic Science 10: 1-7.

Moruf RO, Bolaji OD, Lawal-Are AO. 2018. Biometrics, gut contents and sexual dimorphism of the West African Mud Creeper, Tympanotonus fuscatus var radula from the mangrove swamps of a coastal estuary in Nigeria. Egyptian Journal of Aquatic Biology and Fisheries 22(1): 87- 96.

Moruf RO, Lawal-Are AO. 2017a. Size composition, Growth pattern and Condition factor of two Portunid crabs, Callinectes amnicola (De Rochebrune) and Portunus validus (Herklots) from Lagos Coast, Nigeria. Nigerian Journal of Fisheries and Aquaculture 5(1): 15 - 21.

Moruf RO, Lawal-Are AO. 2017b. Comparability in dietary elements, sex ratio and fecundity of portunid crabs, Callinectes amnicola (De Rochebrune) and Portunus validus (Herklots) off Lagos Coast. Journal of Aquatic Sciences 32 (1A): 25 - 31.

Moruf RO, Lawal-Are AO. 2018. Haemato-biochemical variations in estuarine crabs from a lagoon ecosystem. Journal of Applied Sciences and Environmental Management 22(12): 1899-19033.

Moruf RO, Ojetayo TA. 2017. Biology of the West African fiddler crab, Uca tangeri (Eydoux, 1835) (Decapoda: Ocypodidae) from a mangrove wetland in Lagos, Nigeria. International Journal of Aquatic Biology 5 (4): 263-267.

Onadeko AB, Lawal-Are AO, Igborgbor OS. 2015. Habitat diversity and species richness of brachyuran crabs off University of Lagos Lagoon coast, Akoka, Nigeria. The Bioscientist 3(1): 014- 028.

Parson R. 1988. Statistical analysis- a decision making approach. Second edition. Harper and Row publishers, New York.791pp.

Pauly D. 1983. Some simple methods for the assessment of tropical stocks. FAO Fish. Tech. Pap., 234: 52.

Schneider W. 1990. Field guide to commercial marine resources of the Gulf of Guinea. FAO species identification sheets for fishery purposes. 186pp

Shields JD, Okazaki RK, Kurts AM. 1990. Fecundity and the reproductive potential of the Yellow Rock Crab, Cancer anthony. Fishery Bulletin 89: 299-305.

Usese AI, Lawal-Are AO, Moruf RO, Chukwu LO. 2018. Biomarker Responses to Environmental Stressors in the Hairy Mangrove Crab, Sesarma huzardii (Grapsidae) from a Tropical Lagoon Mudflat in Nigeria. Alexandria Journal of Veterinary Sciences 57 (1): 4-10.

Venkataraman K. 2007. Marine ecosystems of India. Indian Journal of Environmental Education 7: 7-26. 